\title{
Evaluation of Different Onion (Allium cepa L.) Genotypes for Yield and Quality Parameters in Kharif Season under Bengaluru Condition, India
}

\author{
$\operatorname{Das}_{\operatorname{Ratan}^{1 *}}$, R. Veere Gowda ${ }^{1}$ and Himanshu Pandey ${ }^{2}$ \\ ${ }^{1}$ Division of Vegetable Crops, Indian Institute of Horticultural Research, Bengaluru, India \\ ${ }^{2}$ Department of Plant Biotechnology UAS GKVK Bengaluru, India \\ *Corresponding author
}

\section{A B S T R A C T}

Keywords

Allium cepa L.,

Genotypes, Screening,

Yield, Quality

parameters.

Article Info

Accepted:

17 September 2017

Available Online:

10 November 2017
This study was conducted to screen the performance of twenty nine genotypes including one check variety (Arka Pragati) of onion under the agro-climatic condition of Indian Institute of Horticultural Research, Bengaluru, Karnataka during kharif season for yield and quality parameter. We had identified a high yielding germplsm PBR-14-26 (47.44t/ha) which mature on111 days after planting. It also had high number of ring per bulb. Highest ten bulb weight was observed in PBR-14-60 (844.00g) with a considerably higher yield 41.47t/ha. An early maturing genotype PBR-14-59 also been indentified which mature on 82 days after planting. Highest TSS and dry weight was observed in PBR-14-59 $(13.17 \%)$ and PBR-14-60 (15.60\% of fresh wt.) respectively. Plant height was maximum in PBR-14-37(81.58 cm) followed by PBR-14-18. Maximum polar diameter and equatorial diameter was recorded in PBR-14-64 and PBR-14-46 respectively.

\section{Introduction}

Vegetables are important as essential component of human diet. Among the vegetables, onion (Allium cepa L.) often called as "queen of kitchen" is one of the oldest known and an important vegetable crop grown in India. Onion, the principal Allium, ranks second in value after tomatoes on the list of cultivated vegetable crops worldwide, In addition over 20 other Allium species have been consumed by humans. Onion evolution started over 5000 years ago. It has been grown in almost all the parts of India for thousands of years. Onion is a monocot belonging to the family Alliaceae of the class
Liliopsida (Fritisch and Friesen, 2002). A more detailed classification, made by Kazakova (1978), divides onion into three subspecies. Also basis of this classification is geographic origin and the related ecological factors (day length, temperature, and moisture). Each of the subspecies comprises groups of cultivars with common biological and agronomic characteristics. Onion contains a lachrymatic agent, a strong antibiotic in addition to fungicidal, bacterial, anticholestrol, anti-cancer and antioxidant components such as quercetin (Baghizadeh et $a l .$, 2009). In addition, it has been reported to 
be rich in phytochemicals especially flavonols which are medicinal (Javadzadeh et al., 2009). India ranks first in area, second in production and third in export in the world. In India, onion is largely cultivated during rabi season $(60 \%)$ followed by $20 \%$ each in kharif and late kharif season but the productivity is very low at 16.1 tonnes/ha against 22 t/ha in China,b28.9 t/ha in Turkey and 33.7 t/ha in Egypt. On the other hand the quality of the bulb is also very important for the local and processing market. To breed for higher yield and quality it is important to have impressive genotype collection. To achieve the same it is essential to evaluate the genotype from the available gene pool.

\section{Materials and Methods}

The experiments were carried out at Indian Institute of Horticultural Research, Bengaluru, Karnataka during kharif season. Twenty nine genotypes were evaluated for yield and quality parameters including one check varieties (Arka Pragati). Forty-five (45) days old seedlings were planted in randomized complete block design with three replication in the main field at spacing of $10 \times$ $15 \mathrm{~cm}$. Normal package of practices were followed for the cultivation.

Total eighteen observations were identified for this experiment. Plant height was measured from neck of the bulb to the tip of the longest leaf and expressed in centimetre. Number of fully grown green functional leaves was counted on selected plants and the average number of leaves per plant worked out. Leaf orientation observed by visual observation leaf orientation was categories as erect, drooping and semi- drooping type. Leaf shape was witnessed by visual observation leaf shape was categories as tubular and semi tubular type. Days to maturity (days) was observed by number of days taken from transplanting to toppling of vegetative growth in more than half the plant population in each treatment was recorded. Total bulb yield was calculated by adding weight of both marketable and unmarketable bulbs. Ten bulb weight $(\mathrm{g})$ was observed out by weighing ten randomly bulbs from each replication for respective genotype and later the weight were calculated. Neck thickness was measured with the help of Vernier callipers just above the top of the bulb and presented in centimetre. Equatorial diameter of the bulb $(\mathrm{cm})$ is bulb diameter at the maximum thickness of the bulb across the polar length. It was measured with the help of Vernier callipers. Polar diameter of the bulb $(\mathrm{cm})$ is the length between two polar ends of bulbs. It was recorded with the help of vernier callipers and mean diameter was calculated.

Number of rings per bulb is the number of complete fleshy rings encircling the growing centre. Those rings were counted and recorded, when the bulbs were cut across the equatorial region. Number of centres per bulb represent numbers of meristematic areas per growing point surrounded by complete circular rings was recorded in each bulb, when the bulbs were cut at equatorial region. The number of double or multiple centered bulbs in each line were noted. The total soluble solids were recorded with the help of hand refractometer in bulbs and the average was calculated. In case of dry matter content (\%), $100 \mathrm{~g}$ of fresh sample of the bulb was dried in the oven at $65^{\circ} \mathrm{C}$ for to get consistent dry weight. Bulb colour was observed visually after curing. For this parameter only outer most scale colour was taken in consideration. In case of marketable bulb yield ( $\mathrm{t} / \mathrm{ha}$ ), harvested bulbs were categorized into good, undersized, rotten, split and bolted. The weight of the unmarketable bulb was recorded in $\mathrm{kg}$ and calculated in tons per hectare. Split bulbs weight (t/ha) was recoated by weighing of split bulbs right after harvesting. Rotted bulb weight (t/ha) was 
recoated by weighing of spoiled bulb due to rotting after harvest was recorded and expressed in $t / h a$. Weight of the bolted bulb was recorded.

\section{Results and Discussion}

In respect to plant height genotype PBR-1418, PBR-14-37, PBR-14-162, PBR-14-63 and PBR-14- 90 were significantly superior over the control Arka Pragati but PBR-14-37 was significantly superior over all other genotype. Number of leaf is an important parameter for onion plant. Among all the genotype only two genotype i.e. PBR-14-50 and PBR-14-60 were significantly superior over control but those two genotypes was at per. Equatorial diameter and polar diameter determine the shape and size of the bulb which is important for the market value. In the present study PBR-14-7, PBR-14-25, PBR-14-32, PBR-1438, PBR-14-46, PBR-14-70 and PBR-14-82 were significantly superior over Arka Pragati on the other hand PBR-14-12, PBR-14-37, PBR-14-46, PBR-14-70, PBR-14-71 and PBR-14-82 were significantly superior (Table 1).

Neck thickness is one of the most important parameter when we consider the shelf life of onion. In general it being consider that the less neck thickness the more self-life as large neck thickness provide more surface area to microbes for infection. Bulbs with thin necks store longer than bulbs with thick necks (Gautam et al., 2006). Thick bulb necks take longer to dry off after harvesting and provide a high risk for infection of post-harvest storage diseases such as bacterial soft rot (Pseudomonas gladioli pv. alliicola Burkholder) (Peters et al., 1994). In this observation none of the genotype shown superiority over control for neck thickness. Verity or genotype having more ring per bulb are being preferred and also help to increase the bulb size. Thirteen genotypes were shown significantly more no of ring per bulb over control but genotype PBR-14-82 hade maximum number of ring per bulb. Higher TSS and higher dry weight are mainly important for processing purpose, in this study six genotypes had shown significantly higher TSS and only four genotypes PBR-1450, PBR-14-59, PBR-14-60 and PBR-14-63 had shown superiority over control but not that high that the genotype may use as a breeding material for processing treads (Table 1). PBR-14-50, PBR-14-59, PBR-14-60 and PBR-14-63 were shown their significant superiority over control (12\%) for the bulb dry weight. Genotype PBR-14-60 (15.6\%) had maximum dry weight even though it can't be use for the same as The dry weight of commercial dehydrator onion cultivars is usually $\geq 18 \%$ (Arthur, 1999). Single centered onion bulbs are being preferred by the consumer especially for salad purpose. Among the evaluated genotype only two genotypes found i.e. PBR-14-44 and PBR-14111 to be single centered. For any horticultural crop colour is an important parameter for the consumer.

Never less colour is also a very important parameter for the local market and also for export purpose. Two genotype viz. PBR-1444 and PBR-14-111 were found to be yellow, PBR-14-38, PBR-14-44, PBR-14-50 were found to light yellow, PBR-14-12, PBR-1431, PBR-14-32, PBR-14-46 were light red and rest 20 genotype were found to be red in colour. Onion bulb colours are inherited in a complex manner and involve epistatic interaction and the loci might code for enzymes involved in the anthocyanin synthesis. This bulb colour must be due to the genetic makeup of the genotype. Park et al., (2013) developed functional CAPS markers for two inactive DFR-A alleles, DFR-APS and DFR-ADEL, for detection of inactive DFR-A alleles responsible for a failure of anthocyanin production in onions. 
Table.1 Plant height, number of leaf and other qualitative parameter of evaluated onion genotype

\begin{tabular}{|c|c|c|c|c|c|c|c|c|c|c|}
\hline Genotype & $\begin{array}{l}\text { Plant } \\
\text { height } \\
(\mathrm{cm})\end{array}$ & $\begin{array}{c}\text { No. of } \\
\text { leaf } \\
\text { (no.) }\end{array}$ & $\begin{array}{l}\text { Equatorial } \\
\text { diameter } \\
(\mathrm{cm})\end{array}$ & $\begin{array}{c}\text { Polar } \\
\text { diameter } \\
(\mathrm{cm})\end{array}$ & $\begin{array}{l}\text { Neck } \\
\text { thick } \\
\text { ness } \\
(\mathrm{cm})\end{array}$ & $\begin{array}{c}\text { No. } \\
\text { of } \\
\text { ring } \\
\text { (no.) }\end{array}$ & $\begin{array}{l}\text { TSS } \\
(\%)\end{array}$ & $\begin{array}{l}\text { Dry } \\
\text { Weig } \\
\text { ht } \%\end{array}$ & $\begin{array}{c}\text { No. } \\
\text { of } \\
\text { centre } \\
\text { (no) }\end{array}$ & $\begin{array}{c}\text { Bulb } \\
\text { colour }\end{array}$ \\
\hline PBR-14-7 & 52.34 & 8.70 & $4.87 *$ & 4.57 & 0.59 & $7.11 *$ & 11.13 & 12.00 & 1.55 & $\mathrm{R}$ \\
\hline PBR-14-12 & 62.78 & 8.90 & 4.60 & $5.12 *$ & 0.69 & $7.44 *$ & 9.51 & 11.67 & 1.78 & LR \\
\hline PBR-14-13 & 70.3 & 7.90 & 3.91 & 4.11 & 0.68 & $6.67 *$ & 9.39 & 10.67 & 1.33 & $\mathrm{Y}$ \\
\hline PBR-14-14 & 45.84 & 8.10 & 3.63 & 4.11 & 0.60 & 6.00 & 10.42 & 10.67 & 1.44 & $\mathrm{Y}$ \\
\hline PBR-14-15 & 63.98 & 8.60 & 3.52 & 4.05 & 0.29 & 6.11 & 10.11 & 9.00 & 1.11 & $\mathrm{R}$ \\
\hline PBR-14-18 & $72.46^{*}$ & 7.50 & 4.06 & 4.65 & 0.74 & 7.22 & 9.53 & 9.67 & 1.22 & $\mathrm{R}$ \\
\hline PBR-14-21 & 63.44 & 8.50 & 2.96 & 3.96 & 0.36 & 5.67 & 9.80 & 10.67 & 1.11 & $\mathrm{R}$ \\
\hline PBR-14-24 & 50.54 & 7.70 & 4.73 & 4.47 & 0.87 & 3.36 & 9.56 & 10.00 & 2.37 & $\mathrm{R}$ \\
\hline PBR-14-25 & 64.46 & 8.80 & $4.92 *$ & 5.32 & 1.16 & $7.66 *$ & 7.96 & 11.00 & 1.89 & $\mathrm{R}$ \\
\hline PBR-14-26 & 63.66 & 8.50 & 4.57 & 4.78 & 0.68 & $7.44^{*}$ & 10.25 & 11.67 & 1.67 & $\mathrm{R}$ \\
\hline PBR-14-31 & 46.52 & 7.60 & 4.69 & 4.47 & 0.41 & $6.56^{*}$ & 8.77 & 11.00 & 1.67 & LR \\
\hline PBR-14-32 & 56.14 & 9.30 & $4.75^{*}$ & 4.83 & 1.05 & 7.67 & 11.15 & 11.00 & 1.22 & LR \\
\hline Arka Pragati & 67.10 & 8.60 & 4.31 & 4.49 & 0.54 & 5.44 & 9.91 & 12.00 & 1.10 & $\mathrm{R}$ \\
\hline PBR-14-37 & $81.58 *$ & 8.90 & 4.65 & $5.41 *$ & 0.82 & 7.00 & 9.50 & 10.67 & 1.89 & $\mathrm{R}$ \\
\hline PBR-14-38 & 54.52 & 8.30 & $4.77 *$ & 4.91 & 0.95 & 7.56 & $12.06^{*}$ & 11.67 & 2.00 & LY \\
\hline PBR-14-44 & 40.12 & 8.10 & 3.32 & 3.78 & 0.33 & 5.22 & $11.24^{*}$ & 12.67 & 1.00 & LY \\
\hline PBR-14-46 & 45.66 & 8.70 & $4.80^{*}$ & $5.60 *$ & 1.00 & $8.00^{*}$ & 9.92 & 10.00 & 1.22 & LR \\
\hline PBR-14-50 & 52.02 & $10.00 *$ & 4.23 & 4.29 & 0.76 & $6.89 *$ & $11.89 *$ & $13.6^{*}$ & 1.67 & LY \\
\hline PBR-14-59 & 59.98 & 8.2 & 4.48 & 4.18 & 0.58 & 5.11 & $13.17^{*}$ & $14.3^{*}$ & 1.55 & $\mathrm{R}$ \\
\hline PBR-14-60 & 48.42 & $10.00^{*}$ & 4.07 & 3.89 & 0.46 & 4.45 & $12.24^{*}$ & $15.6^{*}$ & 1.55 & $\mathrm{R}$ \\
\hline PBR-14-62 & 72.04* & 8.00 & 4.33 & 4.68 & 0.84 & $6.56 *$ & 10.11 & 12.67 & 1.89 & $\mathrm{R}$ \\
\hline PBR-14-63 & $68.32 *$ & 8.00 & 4.09 & 3.62 & 0.49 & 6.22 & $12.47^{*}$ & $14.0 *$ & 1.56 & $\mathrm{R}$ \\
\hline PBR-14-64 & 54.18 & 8.60 & 4.03 & 4.06 & 0.38 & $6.78 *$ & 9.67 & 11.33 & 1.44 & $\mathrm{R}$ \\
\hline PBR-14-70 & 39.28 & 7.20 & $5.16^{*}$ & $5.05 *$ & 0.55 & $7.89 *$ & 10.50 & 12.67 & 1.33 & $\mathrm{R}$ \\
\hline PBR-14-71 & 46.22 & 7.00 & $5.05 *$ & $5.14 *$ & 0.78 & $7.33 *$ & 9.38 & 10.67 & 1.67 & $\mathrm{R}$ \\
\hline PBR-14-73 & 57.04 & 6.70 & 4.43 & 5.04 & 0.76 & $8.44^{*}$ & 10.47 & 11.67 & 1.11 & $\mathrm{R}$ \\
\hline PBR-14-82 & 47.3 & 7.20 & $4.80^{*}$ & 4.37 & 0.66 & $7.33^{*}$ & 10.33 & 10.67 & 1.67 & $\mathrm{R}$ \\
\hline PBR-14-90 & $75.1 *$ & 7.40 & 4.13 & 4.46 & 0.58 & 6.00 & 9.33 & 10.67 & 1.22 & $\mathrm{R}$ \\
\hline PBR-14-111 & 57.66 & 6.1 & 3.88 & 4.01 & 0.39 & 5.56 & 8.02 & 10.33 & 1.00 & $\mathrm{R}$ \\
\hline $\mathrm{CD} \mathrm{p}=0.05$ & 0.94 & 1.34 & 0.43 & 0.61 & 0.23 & 1.09 & 1.13 & 1.48 & 0.51 & \\
\hline
\end{tabular}

Y, LY, R and LR are yellow, light yellow, red and light red respectively. 
Table.2 Maturity and other yield parameter of the evaluated onion genotype

\begin{tabular}{|c|c|c|c|c|c|c|c|}
\hline Genotype & $\begin{array}{l}\text { Total } \\
\text { yield } \\
(\mathrm{t} / \mathrm{ha})\end{array}$ & $\begin{array}{c}\text { Marketable } \\
\text { yield }(\mathrm{t} / \mathrm{ha})\end{array}$ & $\begin{array}{c}\text { Un } \\
\text { marketable } \\
\text { yield (t/ha) }\end{array}$ & $\begin{array}{l}\text { Rotten } \\
\text { bulb } \\
\text { weight } \\
\text { (t/ha) }\end{array}$ & $\begin{array}{c}\text { Ten bulb } \\
\text { weight } \\
\text { (gm.) }\end{array}$ & $\begin{array}{c}\text { Weight } \\
\text { of split } \\
\text { bulb } \\
\text { (t/ha) }\end{array}$ & Maturity \\
\hline PBR-14-7 & 31.18 & 17.43 & $13.75^{*}$ & $13.75^{*}$ & 383.33 & 0.00 & 85 \\
\hline PBR-14-12 & 25.24 & 22.70 & 2.54 & 2.54 & 633.33 & 0.00 & 89 \\
\hline PBR-14-13 & 13.33 & 10.16 & 3.18 & 3.18 & 450.00 & 0.00 & 95 \\
\hline PBR-14-14 & 13.30 & 11.86 & 1.44 & 1.44 & 350.00 & 0.00 & 98 \\
\hline PBR-14-15 & 15.39 & 12.96 & 2.43 & 2.43 & 380.00 & 0.00 & 90 \\
\hline PBR-14-18 & 19.26 & 15.71 & 3.56 & $3.56^{*}$ & 200.00 & 0.00 & 92 \\
\hline PBR-14-21 & 9.31 & 8.26 & 1.06 & 1.06 & 100.00 & 0.00 & 94 \\
\hline PBR-14-24 & 33.07 & 30.06 & 3.02 & 1.81 & 450.00 & 1.21 & 80 \\
\hline PBR-14-25 & $41.43^{*}$ & 30.35 & $11.08 *$ & $11.08^{*}$ & 666.67 & 0.00 & 90 \\
\hline PBR-14-26 & $47.44 *$ & 34.67 & $12.77 *$ & $5.96 *$ & 400.00 & $6.81 *$ & 111 \\
\hline PBR-14-31 & 23.75 & 14.31 & $9.44 *$ & $9.44 *$ & 450.00 & 0.00 & 110 \\
\hline PBR-14-32 & 24.33 & 22.83 & 1.50 & 1.50 & 680.00 & 0.00 & 93 \\
\hline Arka Pragati & 36.57 & 33.86 & 2.71 & 1.16 & 666.60 & 1.55 & 126 \\
\hline PBR-14-37 & 21.96 & 21.27 & 0.69 & 0.69 & 380.00 & 0.00 & 105 \\
\hline PBR-14-38 & 27.59 & 22.54 & 5.05 & $5.05 *$ & 450.00 & 0.00 & 90 \\
\hline PBR-14-44 & 5.04 & 4.07 & 0.97 & 0.97 & 280.00 & 0.00 & 90 \\
\hline PBR-14-46 & 19.44 & 14.76 & 4.67 & $4.67 *$ & 233.33 & 0.00 & 92 \\
\hline PBR-14-50 & 20.77 & 19.23 & 1.54 & 1.54 & 310.00 & 0.00 & 100 \\
\hline PBR-14-59 & 27.62 & 23.81 & 3.81 & 3.81 & 400.00 & 0.00 & 82 \\
\hline PBR-14-60 & $41.47 *$ & 32.20 & $9.27 *$ & $9.27 *$ & $844.00 *$ & 0.00 & 90 \\
\hline PBR-14-62 & 28.60 & 21.06 & $7.54 *$ & $7.54 *$ & 350.00 & 0.00 & 91 \\
\hline PBR-14-63 & 29.86 & 0.98 & $28.92 *$ & $28.92 *$ & 680.00 & 0.00 & 100 \\
\hline PBR-14-64 & 18.52 & 13.33 & $5.19 *$ & $5.19 *$ & 166.67 & 0.00 & 105 \\
\hline PBR-14-70 & 28.76 & 19.62 & $9.14 *$ & $8.42 *$ & 400.00 & 0.72 & 96 \\
\hline PBR-14-71 & 33.37 & 27.58 & $5.79 *$ & $5.32 *$ & 450.00 & 0.48 & 99 \\
\hline PBR-14-73 & 36.40 & 25.50 & $10.90 *$ & $10.90 *$ & 450.00 & 0.00 & 91 \\
\hline PBR-14-82 & 15.31 & 12.59 & 2.72 & 2.72 & 485.00 & 0.00 & 88 \\
\hline PBR-14-90 & 20.77 & 15.91 & 4.86 & $4.86^{*}$ & 400.00 & 0.00 & 108 \\
\hline PBR-14-111 & 13.29 & 10.66 & 2.63 & 2.63 & 233.33 & 0.00 & 89 \\
\hline$C D p=0.05$ & 4.00 & 2.65 & 2.33 & 2.08 & 174.47 & 0.62 & \\
\hline
\end{tabular}

Yield is the foremost important parameter for any agricultural or horticultural crop. And in case of onion the national average yield/ ha is much lower than many country. In our observation we identified three genotypes i.e. PBR-14-25, PBR-14-26 and PBR-14-60 with significant superiority over control in respect to yield. However genotype PBR-14-26 was significantly superior over all other genotype with a yield of 47.44 t/ha (Table 2 ) on the other hand nun of the genotypes were superior over control for the marketable yield. So work should be done to minimize the unmarketable yield for the genotype PBR-14-26 so that it may be use as a material for yield related breeding program. Many genotypes expressed very high unmarketable yield then the control (Table 2). PBR-14-63 had highest unmarketable yield accounting $28.92 \mathrm{t} / \mathrm{ha}$. And lowest was PBR-1437 with $0.69 \mathrm{t} / \mathrm{h}$ but total yield was not 
impressive enough 21.96t/ha. PBR-14-26 had an unmarketable yield of $12.77 \mathrm{t} / \mathrm{ha}$ but total yield was impressive enough accounting 47.44 t/ha. In the resent study many genotypes were prone to rotting (Table 2).

Genotype PBR-14-63 yielded maximum rotted bulb (28.92t/ha). Bulb rot could be due to Fusarium, Colletotrichum and Scloerotium infection the wide range of weight of rotten bulb among different genotype could be because of the different level of resistance against the pathogens as concluded by Rajapakse and Edirimanna (2002).

In respect to ten bulb weight only one genotype PBR-14-60 (844.00gm) has a significant superiority over Arka Pragati. Among all the genotype, PBR-14-26 (6.81t/ha) yielded maximum Weight of split bulb but it is important to mention that PBR-14-26 had a maximum total yield weight among all the genotype. Bolting is a major problem in onion and all evaluated germplasm was free from bolting. Maturity is again an important parameter.

In our evaluation we observed that all the genotype mature much earlier than the control. Genotype PBR-14-59 mature earliest among all my 82 days and genotype PBR-14-26 matured on 111 days contributing highest total yield in the evaluation. Out of twenty nine genotypes all of them exhibited erect leaf orientation and none of those were semi-drooping or drooping type. Similarly all the genotypes evaluated were exhibiting semi-tubular leaf shape. None of those was having tubular leaf shape. The variation among all the genotype must be because of the genetic factor as similar package of practises was followed during the goring period (Gowda et al., 2016).

\section{References}

Arthur D W and Joe N C. 1999. Yield and dry weight of dehydrator onions after uprooting at maturity and delaying harvest. Hort Science 34(6): 1068-1070.

Baghizadeh A, Baniasadi F, Bonjar G H S, Sirchi G R S, Massumi H, Jorjandi M, Farokhi P R and Aghighi S. 2009. Biocontrol of Botrytis allii Munn the causal agent of neck rot, the post-harvest disease in onion, by use of a new Iranian isolate of Streptomyces. American Journal of Agriculture and Biological Sciences 4: 72-78.

Fritisch and Friesen, (2002): Evolution, Domestication and Taxonomy. Allium Crop Science:

Gautam I P, Khatri B and Paudel G P. 2006. Evaluation of different varieties of onion and their transplanting times for offseason production in mid hills of Nepal. Nepal Agricultural Research Journal 7: 21-26.

Gowda V R., Das R., Ambrish, Halesh G K. and Lichamo J. 2016. Screening of Onion (Allium cepa L.) Genotypes for Yield and Quality Parameters in Open Filed Conditions. Research Journal of Agricultural Sciences. 7(3): 482-486,

Javadzadeh A, Ghorbanihaghjo A, Bonyadi S, Rashidi M R, Mesgari M, Rashtchizadeh $\mathrm{N}$ and Argani H. 2009. Preventive effect of onion juice on selenite-induced experimental cataract. Indian Journal of Ophthalmology 57: 185-189.

Kazakova, A., A., (1978): Luk. Kulturna flora SSSR. Leningrad Recent Advances. (Eds. H.D. Rabinowitch and L. Currah). CAB Internacional 2002.

\section{How to cite this article:}

Das Ratan, R. Veere Gowda and Himanshu Pandey. 2017. Evaluation of Different Onion (Allium cepa L.) Genotypes for Yield and Quality Parameters in Kharif Season under Bengaluru Condition. Int.J.Curr.Microbiol.App.Sci. 6(11): 2393-2398. 